AFRICAN

\title{
Forum*: Leading to environmental sustainability: current status, challenges and prospects of Sino-African low-carbon co-operation
}

\author{
By Liang Yijian** \\ Center for African Studies \\ Yunnan University, China
}

\section{Introduction}

Environmental sustainability is very important for Africa and China. When we seek a solution, low-carbon development at this stage is an important approach. To a certain extent, the low-carbon development is a combination of environmental protection and economic development. China faces great challenges in environmental protection, but it has also made great achievements in low-carbon development, and has certain advantages in terms of capital, technology, and market. The Chinese government has also shown great willingness to change China's development model from high-carbon development to low-carbon development. At present, Africa is at the important stage of protecting its environment while seeking to boost economic development, making low-carbon development a pressing task for African governments. Africa should try to avoid copying the Chinese experience of environmental protection after pollution. In the respect of low-carbon develop-

*Note for the Deputy Editor: Forum pieces are contributions added to each AEAA publication with the aim of promoting and stimulating debate on China-Africa related topics. Forum pieces, unlike all other AEAA articles are not peer-reviewed and allow authors to express their ideas and opinions more freely.

**Liang Yijian is a research associate at the Center for African Studies at Yunnan University. His research interests include Sino-African relations and African governance issues. 
ment, there are many common interests and co-operation possibilities between China and Africa in the age of a heightened China-African relationship. China's technologies in small hydro-power, solar, biogas and other clean technologies are suitable for low-carbon development in Africa.

We know that access to energy is essential for the reduction of poverty and promotion of economic growth. Communication technologies, education, industrialisation, agricultural improvement and expansion of municipal water systems all require abundant, reliable, and cost-effective energy access (UNDP, 2001). Distributed generation using renewable energy systems is one of the best practical solutions to meet rural electrification needs (World Bank, 2000). Since Africa has immense renewable energy resources, making full use of these resources in rural areas, African nations can protect their people, their environment, and their future economic development (Zane Jobe, 2006).

Although there has been rapid development of African economies in recent years, African development still faces many problems, such as a lack of adequate road networks and smart grid, conflict between environmental protection and economic growth, the rising of energy consumption, the trade deficit of fossil energy is widening and the situation of energy security is worsening. These problems are key factors that constrain the development of Africa in general, but can also become important driving forces to promote low-carbon development in Africa. In recent years, many countries invested a lot of money in the field of low-carbon and significantly reduced the unit costs of low-carbon technologies for widely used sources; these will help to combine the international capital and technology with African resources and markets, potentially stimulating low-carbon development in Africa.

In recent years, China-African low-carbon co-operation has become an important component of China-Africa co-operation. In the 4th ministerial meeting of the Forum on China-Africa Cooperation (FOCAC), China proposed eight new measures to promote China-Africa co-operation. As the first of the eight new measures, China proposes to establish a China-Africa partnership in addressing 
climate change. China would enhance co-operation on satellite weather monitoring, development and utilisation of new energy sources, prevention and control of desertification and assist with urban environmental protection. China has decided to build 100 clean energy projects for Africa covering solar power, biogas and small hydro-power. With the rapid development of the world's low-carbon economy and the strengthening of China-Africa co-operation, China-Africa co-operation in the field of low-carbon face broad prospects for co-operation, and better opportunities for development; of course it is also facing some difficulties and challenges.

\section{Current status of China-African low-carbon co-operation}

At present, China-African low-carbon co-operation is still at a preliminary stage. To varying degrees, China and different African countries do have a number of cooperation agreements in low-carbon fields, and the number of projects is constantly growing. Within the framework of FOCAC, China and African countries together held the China-Africa Environmental Protection Co-operation Meeting, implemented the China-Africa human resource training program for environmental protection, and set up the UNEP China-Africa Environmental Center. The Chinese government has proposed to form a partnership between China and African countries in addressing climate change, and strengthen co-operation in different fields. China and African countries have also held in-depth exchanges of views on environmental issues such as international negotiations on climate change to safeguard the common interests of developing countries. The Chinese government has promised not to contend for financial assistance with African countries, but instead will offer them, on the basis of their needs, practical assistances in funds, technology and capacity building in adapting and mitigating climate change.

In recent years, China has carried out a series of projects in the fields of hydropower, biogas technology, solar power and wind power with some African countries. 


\section{Hydropower}

China's low-carbon investment in Africa is mainly in the field of hydropower development. China has some advantages in hydropower technology and Africa has abundant hydropower resources. China has invested in more than 10 African countries' hydropower projects. The total investment in these projects has been more than US\$ 5 billion, China's investment of more than US\$ 3 billion. The largest hydroelectric project under construction is Nigeria Manmubila hydropower project expected to generate 2,600 MW of power in 2018. The followed hydroelectric project is the Merowe dam in Sudan with a hydro-power capacity of $1250 \mathrm{MW}$. In Zambia, too, more than 1,000 MW of hydropower capacity is being developed between the Kafue Lower Gorge and Kariba North projects (Vivien Foster, 2009). Co-operation projects include Mphanda Nkuwa dam on the Zambezi River in Mozambique, Congo River Dam in the Republic of Congo and Bui Dam in Ghana. In April 2012, two hydropower projects have started construction, one is Guinea's largest hydropower project, Keller tower Hydropower, the other is a water conservation project at Côte-d'Or in central Mauritius - much of the cost will be provided by China at low interest rates.

The co-operation of small hydropower between China and African countries is mainly implemented by the International Center on Small Hydro Power (ICSHP) under the "light up Africa" project. China will construct 100 village-level small hydropower stations in 10 African countries (Cameroon, Ethiopia, Kenya, Liberia, Mali, Nigeria, Sierra Leone, Uganda, Zimbabwe, Zambia), to provide electricity for rural communities in Africa, benefiting a population of up to 100,000 people. China will become involved in six African countries, Sierra Leone, Zambia, Zimbabwe, Cameroon and Nigeria to build demonstration projects of small hydropower stations in each country, to promote local social and economic development, and over 300,000 people will directly benefit from this activity (CSTEC, 2011).

\section{Biogas technology}

China has sent biogas experts to some African countries, since the 1980s, to promote biogas technology, to implement many biogas projects that were organised 
by the United Nations, aided by the Chinese government, and for bilateral cooperation. These projects included rural household biogas, large biogas, biogas power generation, urban domestic sewage treatment, the establishment of a national biogas laboratory, biogas resources survey, the development of national biogas development strategic planning and the organisation of various technical personnel training courses (Zhang Mi, 2009). In October 2011, the Chinese Embassy in Sudan donated 25 sets of household biogas devices to the Ta Bate village at White Nile State for the development of animal husbandry (Wu Wenbin, 2010).

The biogas co-operation between China and Africa can be divided into two kinds: one is the factory/farm waste biogas power generation project; the other is rural household biogas technology. The first one can reduce environmental pollution and reduce costs. The second one not only helps to solve the problem of electricity in rural Africa, but is also beneficial to reduce environmental pollution. According to World Bank statistics, three-quarters of households in sub-Saharan Africa, about 500 million people, do not have access to electricity, accounting for a US\$ 38 billion loss to Africa in total each year.

Case I: China's biogas technology assistance projects to Tunisia

From 1998 to 2005, a company in Sichuan province of China has successfully implemented three China-Tunisia biogas technology co-operation projects. The content of these projects include: the general contractor of the biogas power generation demonstration projects, technical training, the establishment of a national biogas laboratory and assistance to develop a national biogas strategic planning capacity.

Case II: Tanzania sisal waste biogas power generation project

This project is a demonstration project of the United Nations Industrial Development Organization (UNIDO) and is the world's first sisal waste to produce biogas and power generation project, completed by the Chengdu Institute of Biology, Chinese Academy of Sciences in co-operation with the German BEB Company.

The project is located in Hale town, Tanga City of Tanzania, with waste residue 
from the Hale sisal processing plant. It generates about $3000 \mathrm{KWh}$ electricity per day and meets the electricity demand of around 300 families. It can also provide a certain amount of cooking energy, and produce about 60 cubic meters of organic fertiliser every day to promote the development of local agriculture.

\section{Solar power}

In recent years, China has developed a variety of solar technologies and products, the quality and quantity of both are at or near the advanced international level. Many China-Africa co-operation agreements have been reached in this field. China plans to build solar power projects in 40 African countries in order to reduce Africa's dependence on fossil fuels, and open a new markets to Chinese manufacturers (China Plans to Light Up Africa with Solar, 2011). Solar water heaters and solar cookers can be widely used in the African regions and China has some advantages in these areas.

In June 2011, China's Ministry of Commerce made a feasibility study on solar energy demonstration projects in Sudan, intended to provide a number of solar street lights for Sudan. In August 2011, Sponsored by the Chinese Ministry of Commerce, Gansu Natural Energy Research Institute hosted the 2011 Frenchspeaking African countries 5 solar energy application technology training classes in Lanzhou. 28 participants engaged in 56 days training coming from 12 countries including Algeria, DRC, Burundi, Senegal, Côte d'Ivoire and Congo-Brazzaville.

\section{Wind power}

China and many African countries have abundant wind resources. This provides a broad platform for China-Africa co-operation. In recent years, China's wind power technology continues to progress and the utilisation of China's wind power is gradually improving. Wind resources in Africa are also very rich, accounting for 20 per cent of the world's wind power capacity (Xinhua News, 2009). At present, the world's fifth largest wind turbine manufacturers - China Goldwind Science \& Technology Co., Ltd. set up offices in Cape Town, South Africa, trying to increase the development of wind energy markets in Africa (China's Commerce Ministry, 
AFRICAN

EAST-ASIAN

AFFAIRS

THE CHINA MONITOR

2011).

\section{Challenges of China-African low-carbon co-operation}

Developed countries are dominating core low-carbon technologies, and the existing international mechanism puts developing countries in a disadvantaged position

In recent years, the United States of America (US), European Union (EU), Japan and other major developed countries have started the implementation of lowcarbon economic development strategies. Low-carbon technologies in developed countries have been taking the lead in the global markets and pose a great challenge for developing countries. An example of this is electric vehicles - Chinese companies have indicated that they do not have independent capabilities in key technologies and systems to produce electric cars.

Currently international low-carbon co-operation has three characteristics:

1. The developed countries have control over the core technologies of lowcarbon, and grasp the right to speak on the international mechanisms

2. Low-carbon co-operation projects are conducted mainly among developed countries, and their technologies are more mature than in developing countries

Developed countries are also dominating the co-operation between the global North and the global South, leaving developing countries in a passive, dependent status

The advantages of the developed countries fall in the areas of investment, technology and other aspects. To some extent it compressed China's space of low-carbon co-operation with Africa. These constraints will inevitably be a big challenge for China if it is to assist in developing low carbon markets in Africa.

Both China and Africa need to transform from high-carbon development to lowcarbon development

The key to achieve low-carbon development is to change the mode of economic 
development, reduce the dependence on coal, oil, natural gas and other fossil fuels. To achieve this, promotion of economic growth that gets rid of high-carbon energy dependence in the process of industrialisation and urbanisation and achieves the transition from high-carbon development to low carbon development is needed. However, China and African countries are still in the framework of the traditional development mode, meaning that changing to energy efficiency is very hard. China and Africa is still in the process of industrialisation and urbanisation. Lowcarbon development cannot be completed within a short time. Even the African's most developed economy, South Africa, is still busy with the process of industrialisation and urbanisation.

The main advantage of many African countries in attracting foreign investment is its rich natural resources, especially oil resources. This forms the economic basis of many African countries. Although low-carbon development in China and Africa has made some achievements there is still a long way to go.

China-Africa economic co-operation is still mainly in the area of trade and lowcarbon co-operation between the two sides is difficult to achieve. Since the founding of the Forum on China-Africa Co-operation (FOCAC), China-Africa relations have witnessed rapid development, but bi-lateral economic co-operation is mainly in resource development and the in the trade of consumer goods. The amount of China's FDI in Africa is rising, but the investment structure, if renewable energy growth is to be achieved, needs to be optimised.

In addition, population growth is a major constraint on China and African countries in achieving low-carbon development. Many African countries have a high rate of population growth, this is bound to have a negative impact on economic growth, increased environmental pressures, increase carbon emissions, and to as a result restrict the low-carbon development co-operation.

Currently, low-carbon development is not the priority for most African countries. The continent needs more electricity to power its economic development

For most African countries, the most important task is to develop their economies 
and to improve the living standards of citizens. For Africa to achieve low carbon development, there are many difficulties:

1. Firstly, Africa's economic structure is still in the transition stage from preindustrialisation to industrialisation. Africa needs more electricity to meet its rising power demand; low-carbon development is not an urgent need for most African countries.

2. Secondly, low-carbon development is a systematic project and cannot be finished overnight and the current energy shortages already limit development.

Thirdly, the lack of capital and technology is another bottleneck for African countries. Low-carbon development requires a lot of money and advanced technologies, especially in the long-term, and sustained investment is needed to ensure sustainable benefits.

It is difficult for China to develop a long-term low-carbon co-operation strategy with African countries. Most of the low-carbon co-operation is attached to other projects, or some small scattered projects. Usually it is a part of China's assistance projects to Africa, or a part of some enterprises' individual business activities, and it is difficult to form the mechanism of low-carbon development co-operation.

In addition, China now is at the top of the list of $\mathrm{CO}_{2}$ emitting countries, and China and African countries do not necessarily have the same view in international climate negotiations.

China and African countries need to deal with the inequalities and imbalances of the existing international system regarding low-carbon development

Many developed countries are unwilling to assume the obligations, and place a greater emphasis on developing countries to achieving low-carbon development. Developed countries are largely responsible for the causes of climate change to date, but future responsibility is shared by developed and developing countries alike. Rapidly developing countries such as China with steeply rising emissions curves must also actively participate in the much needed transition to low-carbon 
development. The development of low-carbon co-operation between China and Africa will be subject to the imbalance of international mechanisms and cannot necessarily take advantage of the characteristics of both sides to co-operate.

China-African low-carbon co-operation has just started; the capabilities of technological transfer and market operation of both sides need to be further improved

In the process of co-operation, Chinese companies need to learn more about the realities of African countries. This is a disadvantage of Chinese companies compared to Western multi-nationals, which have been operating in Africa since long before Chinese companies.

\section{Prospects of China-African low-carbon co-operation}

When analysing the status and challenges of China-African low-carbon cooperation, it is important ot understand that mutual benefit in the long term is essential. Currently, China has become Africa's largest trade partner, and Africa is now a major resource import market for China, its second largest overseas construction project contract market and China's fourth largest investment destination (in terms of regions). China-Africa economic and trade development has improved people's livelihoods and diversified economic development in African countries, it has provided strong support for China's socio-economic development, and contributed to promoting South-South co-operation and balanced world economic development.

The world's transition from high-carbon development to low carbon development is a strategic opportunity for China and African countries to change their economic growth mode

The world's current economic development mode is a high-carbon mode. This economic mode is based on coal and oil as the main source of energy. However, fossil fuels damage the environment which has an effect on human security. With the continuous expansion of the socio-economic scale, this high-carbon development mode is not sustainable. It is likely to cause serious destruction of the ecolog- 
ical environment, and will affect the sustainable development of human society.

In the future, our world's economic development mode will gradually change from high-carbon to low carbon, and China is trying to begin this transition. Such a transition would also be an essential part of China's modernisation. China can make these emissions reductions within the tight constraints of a global $2^{\circ} \mathrm{C}$ target while still meeting development and economic growth goals over the next four decades.

Low-carbon transition presents opportunities for China and African countires to improve their energy security and move their economies up the value chain in the production of international goods and services. In recent years, the international community has done much work to control greenhouse gas emissions, undertaken many research studies and developed new low-carbon technologies. This trend indicates that the low-carbon development is a new economic growth point and is the next strategic high point of the international competition. It is also an important strategic opportunity for China and African countries to change their growth mode.

China-African low-carbon co-operation is highly complementary in the field of capital, technology, resources and markets, so China-African low-carbon cooperation will have broad prospects in the future

We know that energy shortages have limited Africa's the economic development. Efforts to stimulate economic growth in all industries across the continent are being stifled by the lack of reliable electricity. With sub-Saharan Africa needing $270 \mathrm{GW}$ of additional electricity generation capacity to meet its rising power demand, opportunity exists to use Africa's readily available resources such as hydro, gas, coal and other renewable energy resources (Moses Duma, 2009).

African countries are very eager to use small-scale renewable energy technology. Currently, many countries have invested heavily to develop small-scale solar, wind, and hydropower in a bid to provide energy to urban and rural populations. These types of energy production are especially useful in remote locations because 
of the excessive cost of transmitting electricity from large-scale power plants.

In recent years, China has already made considerable progress in developing lowcarbon technologies in a wide range of sectors, especially in the optimisation of energy structures. Policies and innovation strategies that encourage green innovation and investments are being introduced. China has accumulated many advanced technologies and a great deal of experience in the development of energy efficiency and of clean and renewable energy. These technologies are appropriate, cheap, effective, and suitable for application in African countries.

\section{Prospects in solar power}

Africa has immense solar resources. The distribution of solar resources across Africa is fairly uniform. Africa's 80 per cent land can receive about $2000 \mathrm{KWh}$ of solar energy per square meter per year. Many African countries receive on average 325 days of bright sunlight per year. This gives solar power the potential to bring energy to virtually any location in Africa without the need for expensive large scale grid level infrastructural developments. However, currently with $15 \mathrm{GW}$ installed global capacity solar photovoltaic, Africa only accounts for $15 \mathrm{MW}$. South Africa has some of solar cell manufacturing plants, but production capacity at these plants are very limited. At present, the majority of Africa's large-scale solar power generation facilities are mainly concentrated in South Africa and Algeria.

China has become one of the biggest countries of solar energy utilisation in the world, and China is a leading player in some solar energy technologies. Solar power in China is a growing industry. China is the world's largest user of solar hot water systems. The number of China's solar water heaters ranked first in the world. In 2009, the annual production of solar water heaters in China exceeded 40 million square meters, accounting for 50 per cent of world production, the total installed number has reached 145 million square meters, accounting for about 70 percent of world installation. In solar cell technology, China's photovoltaic battery output in 2011 accounted for about 50 percent of global output, ranking first in the world for five consecutive years. 
China enjoys advantages in large-scale as well as small-scale solar power generation technologies. These technologies can be used to generate power on a large scale and can be used to provide power on a smaller scale, helping with day to day needs such as small-scale electrification, desalination, water pumping, and water purification.

\section{Prospects in wind power}

Africa's wind resources are the best around the coasts and in the eastern highlands. Wind is far less uniformly distributed than solar resources. The availability of wind on the western coast of Africa is substantial, exceeding 3,750 KWh, and will accommodate the future prospect for energy demands. Central Africa has lower than average wind resources to work with. It is in Mediterranean North Africa that wind power has been developed at scale. This, too, is where current national policies are set to grow the sector further. At the end of 2009, about 96 per cent of the continent's total wind installations of $763 \mathrm{MW}$ were to be found in Egypt (430 MW), Morocco (253 MW) and Tunisia (54 MW).

In 2010, China's new installed wind power capacity was $18.9 \mathrm{GW}$, and the total installed capacity has reached $42 \mathrm{GW}$, the largest in the world. Targets for individual low-carbon technologies have repeatedly been revised upwards as development outstripped expectations. Wind power growth has caught particular attention - with capacity rising from $13 \mathrm{GW}$ in 2008 to $42 \mathrm{GW}$ in 2010 (equivalent to half the power plant capacity in the UK in 2010). China plans to achieve $100 \mathrm{GW}$ of wind power capacity by 2015 .

Yet in term of technology, China's wind power development lags behind European countries. China's home-grown wind turbine manufacturers such as Goldwind and Sinovel are however amongst the world's top five producers, and produce wind turbines based on domestically-developed intellectual property, with the intention of creating an export market in Europe. Chinese companies have the ability to constantly move from "Made in China" to "Created in China" and from the domestic market to the international market. 


\section{Prospects in hydropower}

Africa's hydropower resources have the potential to significantly contribute to solving the region's power problems. Sub-Saharan Africa has a tropical climate and a significant number of perennial rivers, with a potential to generate 1,750 $\mathrm{TWh}$. The resource uses proven technology and is easily accessible across the region. However, only 7 per cent of this potential has been developed. The exploration of key rivers such as the Zambezi, Congo, Nile, and Niger could provide a solution to Africa's power problems. The Congo River in DRC has the potential to produce over 100,000 MW of electricity, which is sufficient to meet the energy needs of the whole Southern Africa. The Zambezi River can produce 10,000 MW. Other examples include Ethiopia, with a hydro potential of $30,000 \mathrm{MW}$, and Nigeria with over 20,000 MW (Moses Duma, 2009).

China's hydropower industry has three major advantages (low cost, skills, the nation's "go-out" strategy), and has a clear competitive advantage in the global markets. The Chinese Export-Import Bank and other Chinese financial institutions, state-owned enterprises, and private firms are now involved in at least 100 major dam projects overseas. Hydropower is readily available in many African countries, for both large and small scale projects. Hydropower is highly versatile and can be used to meet national electricity grid requirements, rural electrification programs and industrial power needs. Therefore, the hydropower co-operation of China and African countries have broad prospects for the future. It can solve Africa's three problems (electricity, irrigation and water shortage) in one fell swoop.

\section{Although China has a technological gap compared with developed countries, China can continue to reduce the cost of low-carbon products through econo- mies of scale, also reducing the cost for African countries}

Low-carbon products are expensive. Even when the relative difference in buying power, materials cost, opportunity cost, labour cost and overhead are factored in, renewable energy will remain expensive for people who are living on less than US\$ 1 per day. 
In recent years, China has been increasing investment in low-carbon development. China has ranked first in the list of largest clean energy investors in 2010, when investment in China reached US\$ 54 billion, with Germany in second place (US\$ 41 billion) and the USA in third (US\$ 34 billion). China can continue to reduce the cost of low-carbon products by the scale effect of China's huge market, and in doing so provide a safe, reliable and cost effective solution for Africa's rural areas.

Cheaper equipment is also more secure and less vulnerable to attack. This can be an important feature in regions prone to conflict. Cheaper wind and solar power systems are simple to set up, easy to operate, easy to repair, and durable. Wind resources and solar resource are abundant enough to provide all of the electrical energy requirements of rural populations, and this can be done in remote and otherwise fragmented low density areas that are impractical to address using conventional grid based systems (Howells, 2003).

\section{Conclusion and recommendations for China-African low-carbon co-operation}

There are three obstacles in promoting low-carbon development in the subSaharan African region: cost, market structure and risk. In rural areas of subSaharan Africa, less than 10 per cent of households can connect to the electricity grid. Using small-scale wind, biomass and solar systems in rural areas of Africa can reduce costs, and make it easier to expand the existing grid. Structural defects in the African energy market, including corporate monopolies, discourage new investment and the entrance of new technology into the market. This requires government reform of energy management systems to encourage third parties and private power producers to enter the low-carbon market. At the same time, using some risk mitigation tools to deal with political risk, regulatory risk and business risk in the sub-Saharan African region. From the perspective of China-Africa cooperation, the obstacles should be combined with the experience of China-Africa co-operation, and the promotion of the China-Africa energy low-carbon cooperation in the following fields: 
China's investment in clean energy over the years

\begin{tabular}{|c|c|c|}
\hline Year & $\begin{array}{l}\text { The } \\
\text { amount of }\end{array}$ & Important feature \\
\hline 2013 & $\begin{array}{l}\text { US\$ } 54.2 \\
\text { billion }\end{array}$ & $\begin{array}{l}\text { China solidified its position as the world's clean energy } \\
\text { superpower. China maintains the world's most robust } \\
\text { wind market. China accounted for } 28.7 \text { per cent of G-20 } \\
\text { total spending in renewable energy. } 5 \text {-year growth rate } \\
\text { is } 17.8 \text { per cent. }\end{array}$ \\
\hline 2012 & $\begin{array}{l}\text { US\$ } 65.1 \\
\text { billion }\end{array}$ & $\begin{array}{l}\text { China garnered } 25 \text { percent of G-20 solar energy } \\
\text { investment, setting a one-year record with US\$ } 31.2 \\
\text { billion, and } 37 \text { per cent of G- } 20 \text { wind energy } \\
\text { investment, with US\$ } 27.2 \text { billion recorded. China also } \\
\text { registered } 47 \text { percent of G-20 investment in the "other } \\
\text { renewable energy" category that includes small hydro, } \\
\text { geothermal, marine, and biomass. }\end{array}$ \\
\hline 2011 & $\begin{array}{l}\text { US\$ } 45.5 \\
\text { billion }\end{array}$ & $\begin{array}{l}\text { China continued to attract significant investment in } \\
\text { wind, which totalled US\$ } 29 \text { billion in 2011, spurring } \\
\text { deployment of } 20 \mathrm{GW} \text { of wind capacity. }\end{array}$ \\
\hline 2010 & $\begin{array}{l}\text { US\$ } 34 \\
\text { billion }\end{array}$ & $\begin{array}{l}\text { In 2010, China accounted for almost } 50 \text { per cent of the } \\
\text { global wind and solar industry investment. }\end{array}$ \\
\hline 2009 & $\begin{array}{l}\text { US\$ } 34.6 \\
\text { billion }\end{array}$ & $\begin{array}{l}\text { China has become the top of the list of clean energy } \\
\text { investment, }\end{array}$ \\
\hline 2008 & $\begin{array}{l}\text { US\$ } 12.8 \\
\text { billion }\end{array}$ & $\begin{array}{l}\text { The growth rate of China's investment in wind power } \\
\text { market has been ranked second in the world; } \\
\text { investment in solar power generation has become the }\end{array}$ \\
\hline 2007 & $\begin{array}{l}\text { US\$ } 10.8 \\
\text { billion }\end{array}$ & $\begin{array}{l}\text { Most of the funds have been invested in to increase the } \\
\text { installed capacity of wind power. The installed capacity } \\
\text { is twice that of } 2006 \text {. }\end{array}$ \\
\hline
\end{tabular}


AFRICAN

\section{Assistance to Africa}

China should further increase assistance in the field of appropriate low-carbon technologies and green agricultural technologies to Africa, making it a highlight of the China-African low-carbon co-operation. This will help improve the effectiveness and reputation of China's assistance.

Chinese finance often goes to large-scale infrastructure projects, with a particular focus on buildings, hydropower generation and railways. More than 35 African countries are engaging with China on infrastructure financial assistance, with the biggest recipients being Nigeria, Angola, Sudan, and Ethiopia. China could further increase assistance in the field of low-carbon appropriate technologies and green agricultural technologies. On the one hand, this can spread China's low-carbon technologies and products to the African market, and on the other hand, it can diversify the forms of China's assistance to Africa.

\section{Technical co-operation}

Technical co-operation should include establishing an effective mechanism of China-Africa technical co-operation through the combination of China's advantages in technology and capital with Africa's advantages in low-carbon resources and labour; and, establishing a China-Africa Technical Co-operation Fund, to promote the application and transfer of low-carbon technologies in Africa to ensure that African countries can get China's low-carbon technologies at reasonable costs. In the long run, China-Africa low-carbon technology transfer can help improve Africa's investment environment and form the industrial chain between China and Africa.

\section{Chinese government}

In order to better integrate China's advantageous resources in low-carbon, and help China's low-carbon businesses to invest in Africa, the Chinese government should formulate strategic plan and provide the necessary support and services for China's companies in Africa to reduce risk. 


\section{Formulating China's long-term low-carbon investment plan in Africa}

On the basis of analysis of the advantages of both sides, African governments, in corporation with China should formulate a long-term low-carbon investment plan in Africa for China. The plan should have a clear choice on the location and industry of China's investment in Africa and set out some preferential policies for China's companies in Africa. In the choice of location (from the Chinese side), China should give priority to the African countries that have low-carbon resources, preferential policies and friendly relations with China. In the choice of industry, China should give priority to the industries that will be most suitable for the actual on the ground situation in Africa and are able to take advantage of Africa's low-carbon resources and China's technologies.

The Chinese government and Chinese financial institutions should support Chinese low-carbon companies to invest in Africa:

1. Financial organisations and policy banks in China should increase the loan amount, and to provide Chinese companies with good financial support, reduce the overall costs of the enterprise, enhance the competitiveness of enterprises.

2. China's commercial banks and private capital should be encouraged to invest in Africa's low-carbon field, getting the support from the venture capital funds and opening up channels for international financing. In addition, in order to reduce the investment risk, China should establish overseas investment insurance systems as soon as possible and help enterprises avoid risks and improve project success rates.

3. An expert advisory committee for China-African low-carbon co-operation should be established. It will serve the major projects of China's low carbon companies in Africa, and provide decision-making advisory services and technical guidance for these companies.

A China low-carbon Enterprise Development Association should be established to co-ordinate China's low-carbon development. At present, many of China's low 
carbon enterprises lack international business experience and are is still only in the initial stages of becoming transnational businesses.

\section{Chinese enterprises}

In recent years, Chinese investment in Africa has grown rapidly, however this is still limited in comparison to the potential. Many Chinese low carbon businesses are willing to go out, but they are not familiar with the investment environment in Africa and lack the necessary experience of overseas investment.

As a type of market-seeking investment, China low-carbon companies should clearly understand their investment target in Africa and have a long-term strategic investment plan. At present, most of China's enterprises in Africa are resourceseeking enterprises, they lack the long-term business objectives and generally hope to have "bigger economic returns and smaller investment", and lack the long-term strategic considerations in the African market.

These companies should do market research and project feasibility analysis. The situation in Africa is complex, companies should not blindly implement crossborder investment and operation. A comprehensive understanding of the African country's political, economic, and cultural knowledge is necessary. They should fully estimate the political risk and economic risk and make the right investment decision.

The Chinese low carbon companies should speed up the indigenisation process of their businesses in terms of market, management and capital.

Overall, China's investment in Africa contains both risks and opportunities. Chinese enterprises should actively and safely deal with the short-term risks, and seize the long-term opportunities. When analysing the four main motivations of investment (cheap labour, local market, supply of raw materials and abundant natural resources), Africa's huge population, markets and resources are incomparable advantages to attract low-carbon FDI in the future. This requires China to careful analyse the situation of the various development stages, and combine China's lowcarbon investment projects in Africa with the elements of China's traditional 
strengths, special resources, and competitive enterprises. In the process of lowcarbon co-operation, China-African low-carbon co-operation faces a monumental challenge and a historic opportunity. The transition to a low-carbon economy will require large investments and advanced technologies but will also bring about substantial benefits.

The path of low-carbon development not only creates a viable method for solving the global development predicament, but brings strategic opportunities to the majority of the developing world to achieve leapfrog development. If Africa wants to take advantage of this rare strategic opportunity, the future reform is essential. Firstly, low-carbon development for Africa is needed to achieve leapfrog development and it has important strategic significance. African governments should develop low-carbon development goals and give priority to low-carbon development. Secondly, Africa should exploit the advantages of resources rather than simply exporting raw materials to the developed economies or fast-growing emerging markets. African countries should strive to break the monopoly and national protectionism and create conditions for sustained external capital and technology in the field of low-carbon technologies and industries to strengthen African new energy industries. Thirdly, low-carbon development will help African countries to achieve economic diversification. Diversification is a sign of maturity of an economy. African countries can rely on low-carbon development as an opportunity to adjust and optimise their industrial composition. Fourthly, Africa's development requires a lot of investment to electrify Africa, especially in rural areas. Lowcarbon technologies can provide localised off-grid solutions that provide electricity to off-grid areas. This requires the government to encourage third parties and private-power-producers to enter the low-carbon market and reduce business risk.

The widespread use of mobile phones helped Africa leapfrog the wired telephone era and achieve development through a new technology; low-carbon development can help African countries to break through the bottleneck restricting development in the form of energy shortages. The solution to the problem is complex, but China -African low-carbon co-operation will help solidify the foundation of Africa's economic development, increase investment in infrastructure construction, 
AFRICAN

transport, manufacturing and small and medium-sized enterprises. In addition it will increase Africa's capacity for independent development. Capital, equipment and technologies from China have effectively helped and will continue to reduce construction costs for African countries and improve their infrastructure situations.

\section{Bibliography}

China Plans to Light Up Africa with Solar. 2011. [Online]. Available: http:// www.iol.co.sa/business/international/china-plans-to-light-up-africa-withsolar-1.1080600 [2014, April 10].

China's Commerce Ministry. 2011. Chinese Wind Power Companies Targeting the African Market [Online]. Available: http://www.mofcom.gov.cn/aarticle/i/ jyjl/k/201103/20110307450321.html [2014, April 10].

CSTEC (China Science and Technology Exchange Centre). 2011. South-South Cooperation on Science and Technology to Address Climate Change Applicable Technology Manual. [Online]. Available: http://www.actc.com.cn/ UpLoadFiles/Attached/file/20120605/20120605105916_4745.pdf [2014, April 10].

Duma, M. 2009. Hydropower: Africa's Solution to the Electricity Crisis! [Online]. Available: http://www.frost.com/prod/servlet/market-insight-top.pag? docid=169253081[2014, April 10].

Foster, V. 2009. Building Bridges-China's Growing Role as Infrastructure Financier for Sub-Saharan Africa. The World Bank's Trends and Policy Options. No.5: 21.

Howells, M. I. et al. 2003. An Energy Model for a Low Income Rural African Village. [Online]. Available: http://www.etsap.org/ worksh_6_2003/2003P_howells.pdf [2014, April 10].

Jobe, S. 2006. Alternative energy sources for electricity generation: Their 'energy 
effectiveness' and their viability for undeveloped and developing countries. [Online]. Available: http://www.ecoguinea.org/uploads/5/4/1/5/5415260/ alternative_energy_sources_for_electricity.pdf [2014, April 10].

Shang, M. 2009. China Biogas Technology in Africa Retrospect and Prospect [Online]. Available: http://www.newenergy.org.cn/ Html/0094/4140926551.html[2014, April 10].

UNDP (United Nations Development Programme). 2001. The Human Development Report 2001. [Online]. Available: http://hdr.undp.org/reports/ global/2001/en/ [2014, April 10].

Wenbin, W. 2010. The Biogas Lamp Lights White Nile [Online]. Available: http:// env.people.com.cn/GB/12923787.html [2014, April 10].

World Bank. 2000. Expanding Electricity Access to Remote Areas: Off Grid Rural Electrification in Developing Countries. [Online]. Available: http:// www.martinot.info/Reiche_et_al_WP2000.pdf [2014, April 10].

Xinhua News. 2009. More and More African Countries Favour Wind [Online]. Available: http://news.xinhuanet.com/fortune/2009-07/30/ content_11796428.htm [2014, April 10]. 